\section{Getting to the heart of matters}

\author{
Eleanor Tillett
}

Welcome to the 2017 British Association of Sport \& Exercise Medicine (BASEM) issue of the number one ranked journal in sports sciences/sports medicine/orthopaedics/rehabilitation. Following on from BASEM's recent Spring Meeting we look at 'Hearts and Minds'. The heavyweight of this issue is undoubtedly the consensus paper-'International Criteria for Electrocardiographic Interpretation in Athletes' (see page 704) by University of Washington's Professor Jonathan Drezner and his international all-star team. The expert group met in Seattle in 2015 to develope 'a clear guide to the proper evaluation of ECG abnormalities in athletes'. As you'll see from the detail of this paper there is much on which to update ourselves. It's open access so please share it using the 'share tab' which sits alongside every BJSM piece.

In balance to this in-depth look at elite athlete cardiac issues we have a PEDro Systematic Review Update: Exercise for coronary heart disease (see page 755 ). The argument for physical activity to promote heart health has obviously been well won, and here is the latest on the 'how'.

\section{MIND-BODY CONNECTION}

As we continue to search for the holy grail of the underlying driving forces in tendinopathy, Adrian Mallow and his UK/ Australan team reviews 'The association of psychological variables and outcome in tendinopathy' (see page 743). Most of their evidence comes from studies on lateral epicondylalgia with 'moderate evidence linking catastrophisation and distress'. The evidence is less clear when it comes to other tendinopathies. Along the same lines Liam Maclachlan from the University of Queensland (see page 732) discusses 'The non-physical features of patellofemoral pain'. We can probably all recall patients with patellofemoral pain in whom we think psychological factors may play a role but as Maclachlan highlights, the exact relationship between the physical and psychological remains to be defined. For more on patellofemoral pain I commend the 2016 international consensus statements to you. ${ }^{12}$ And, remember the

Division of Surgery and Interventional Science, University College London, London, UK

Correspondence to Dr Eleanor Tillett, University College London, Division of Surgery and Interventional Science, UCL Medical School, 74 Huntley St, WC1E 6AU London, UK; e.tillett@ucl.ac.uk
2017 international Patellofemoral Research Retreat is on the (sunny) horizon-Gold Coast, Australia, July 18-20 (https://ipfrn. org/conference/)

\section{IT'S WHAT IS ON THE INSIDE THAT COUNTS}

Looking inside means more than just tissue imaging and mental reflection; our gut microbiota may be influencing our musculoskeletal health from within. In two editorials, both from Ireland, Alan Rankin (see page 698) and Owen Cronin (see page 700) discuss the emerging evidence of the influence of exercise on gut health and lso the potential links between gut microbes and general health, musculoskeletal health and sports performance. A provocative Canadian book gives parenting advice under the title 'Let them eat dirt' (http:// letthemeatdirt.com/). Probiotics anyone?

\section{BMJ E-LEARNING}

Let me recommend two BMJ e-learning modules. If you feel your ECG skills are a little wanting then check out the ubuiquitous professor Drezner's module on 'ECG interpretation in athletes'. (http://ow.ly/ Vnd630ao04w). It's free after you provide a few details-will take you 30 seconds to get started. Or maybe you have the seed of a research idea but feel overwhelmed by the process of putting it into action? If so then the 'Research to publication' module (http://learning.bmj.com/learning/ rtop/login.html) may be just what you're looking for. Dr Adam Culvenor, BJSM's continuing physiotherapy education editor from Austria, highlights this in his editorial (see page 694).

\section{INVITATION TO BATH-12-13 OCTOBER 2017}

Please consider this your invitation to BASEM's annual congress (figure 1) in Bath on 12-13 October 2017 (https:// tinyurl.com/mor9csl). One highlight will be specialist sessions throughout the conference. These high-level masterclasses will include tendinopathy, concussion, and sports injury prevention.

There's also a great programme for the clinician in 'part-time' sport and exercise medicine. The sessions on musculoskeletal injury and arthritis, courtesy of Arthritis Research UK, are loaded with speaker talent; and back by popular demand from

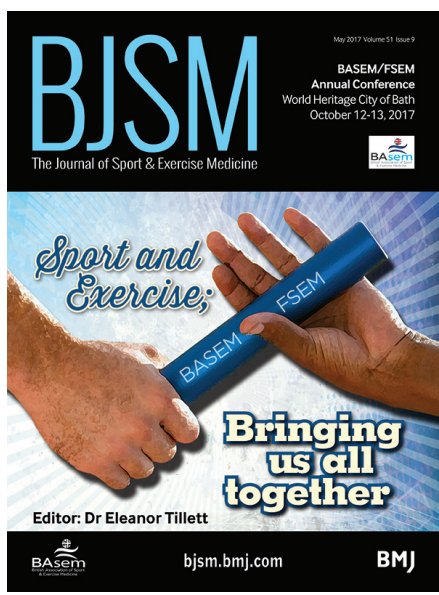

Figure 1 Invitation to BASEM/FSEM Conference 2017

2016, is a practical session on implementing and prescribing physical activity for health.

A vigorous UK community is committed to seeing SEM thrive even more strongly and collaboration and co-operation among all SEM organisations and interested parties is key. 2017 is the fourth year of BASEM and the Faculty of Sport and Exercise Medicine have partnered to deliver the conference and this year we are delighted to be joined by the University of Bath who are celebrating their $50^{\text {th }}$ anniversary. The premise of the conference to 'bring us all together' is therefore very timely. I look forward to seeing you in Bath for a great two days.

\section{Competing interests None declared.}

Provenance and peer review Commissioned; internally peer reviewed.

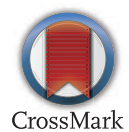

To cite Tillett E. Br J Sports Med 2017;51:693.

Br J Sports Med 2017;51:693.

doi:10.1136/bjsports-2017-097849

(c) Article author(s) (or their employer(s) unless otherwise stated in the text of the article) 2017. All rights reserved. No commercial use is permitted unless otherwise expressly granted.

\section{REFERENCES}

1 Crossley KM, Stefanik JJ, Selfe J, et al. 2016 patellofemoral pain consensus statement from the 4th international patellofemoral pain research retreat, manchester. part 1: terminology, definitions, clinical examination, natural history, patellofemoral osteoarthritis and patient-reported outcome measures. Br J Sports Med 2016;50:839-43.

2 Crossley KM, van Middelkoop M, Callaghan MJ, et al. 2016 patellofemoral pain consensus statement from the 4th international patellofemoral pain research retreat, manchester. part 2: recommended physical interventions (exercise, taping, bracing, foot orthoses and combined interventions). Br J Sports Med 2016;50:844-52. 